\title{
Penerapan Metode POGIL Pada Materi Konsep Mol Di Kelas X IPA SMA Negeri 2 Langowan
}

\author{
Gloria Manampiring ${ }^{* a}$, Ignatius Santoso ${ }^{a}$, Ardi Kapahang ${ }^{b}$
}

${ }^{a}$ Kimia, FMIPA, Universitas Negeri Manado, Minahasa, 95618, Indonesia

\begin{tabular}{l} 
I N F O A R T I K E L \\
\hline Diterima Oktober 2019 \\
Disetujui Desember 2019 \\
\\
\hline Key word: \\
POGIL \\
Learning Outcomes \\
Mol Concept \\
\hline Kata kunci: \\
POGIL \\
Hasil Belajar \\
Konsep Mol \\
\hline
\end{tabular}

*e-mail:

gloria.manampiring12@gmail.com

*Telp: 089529452397

\begin{abstract}
A B S T R A C T
The purpose of this study was to determine the application of the POGIL method to the learning outcomes of Grade X Science students on the mole concept material.This research was implemented in class XIPA 1 and X IPA 2 SMA Negeri 2 Langowan school year 2018/2019. The method used is experimental method with post - test only control design research. In this study applied different methods on 2 classes namely POGIL class and lecture class with the number of students of each class of 23 students. Student learning Data is derived from the post-test value. Data analysis uses test-T with a significant level of $\alpha=0.05$. Analysis of student learning statistics test results obtained the value $T>T$ table or $4.31>1.68$. So that the $H_{1}$ can be concluded accepted and Ho rejected, this shows that students 'learning outcomes with the application of the POGIL method are greater than the student learning outcomes by the lecture method on the concept of Mole material.
\end{abstract}

\author{
A B S T R A
}

Tujuan dari penelitian ini adalah untuk mengetahui penerapan metode POGIL terhadap hasil belajar siswa kelas X IPA pada materi konsep mol. Penelitian ini dilaksanakan di kelas X IPA 1 dan X IPA 2 SMA Negeri 2 Langowan tahun ajaran 2018/2019. Metode yang digunakan adalah metode eksperimen dengan desain penelitian post - test only control design. Dalam penelitian ini diterapkan metode yang berbeda pada 2 kelas yaitu kelas POGIL dan kelas Ceramah dengan jumlah siswa masing-masing kelas 23 siswa. Data hasil belajar siswa diperoleh dari nilai post-test. Analisis data menggunakan uji-t dengan taraf signifikan $\alpha=0,05$. Analisis uji statistik hasil belajar siswa diperoleh nilai t hitung $>\mathrm{t}$ tabel atau 4,31>1,68. Sehingga dapat disimpulkan $\mathrm{H}_{1}$ diterima dan $\mathrm{H}_{0}$ ditolak, ini menunjukan bahwa hasil belajar siswa dengan penerapan metode POGIL lebih besar dari hasil belajar siswa dengan metode Ceramah pada materi konsep mol.

\section{Pendahuluan}

Pendidikan yang berkualitas dapat mendorong kemajuan suatu bangsa, karena pendidikan bermanfaat tidak hanya dibidang pengetahuan, tetapi juga memberikan pengalaman yang mampu membentuk karakter peserta didik yang dapat diterapkan dalam kehidupan sehari-hari sehingga bermanfaat bagi lingkungan sekitarnya.

Dalam pembangunan bangsa pendidikan merupakan aspek yang sangat penting karena karakter suatu bangsa dapat dibentuk dan dikembangkan melalui aspek pendidikan [1]. Proses pengembangan pendidikan yang berkualitas tidak terlepas dari kegiatan belajar dan mengajar. Melalui proses pembelajaran yang baik peserta didik dapat menumbuhkembangkan minat, bakat dan kepribadian sesuai dengan potensi yang dimiliki oleh masing-masing peserta didik. Pembelajaran yang baik bagi peserta didik inilah yang membawa pengaruh penting dalam pengembangan diri untuk menjadi individu yang berkompetensi dibidangnya. 
Salah satu bidang pendidikan yang penting untuk dipelajari dan dipahami adalah ilmu kimia. Kimia memuat rumus-rumus, hukumhukum dan konsep yang menghubungkan materi satu dengan yang lainnya, dalam pembelajaran siswa dituntut untuk memahami, mengaitkan, dan mengaplikasikan konsep tersebut dalam kehidupan sehari-hari. Penguasaan konsep kimia merupakan hal paling penting dalam pembelajaran kimia [2].

Berdasarkan observasi di SMA Negeri 2 Langowan, banyak siswa yang tertarik dengan ilmu pengetahuan alam, banyak siswa yang suka untuk masuk bidang peminatan IPA, namun ada kendala yang dialami oleh siswa yaitu kurangnya pemahaman mereka tentang materi kimia, sehingga siswa tidak aktif dalam kegiatan pembelajaran. Materi Konsep mol merupakan materi yang dianggap sulit sehingga kurang diminati oleh siswa dan hasil belajar siswa pada materi konsep mol masih rendah. Adapun KKM (Kriteria Ketuntasan Minimal) yang ditetapkan untuk mata pelajaran kimia di SMA Negeri 2 Langowan yaitu 70 namun yang capai KKM hanya $40 \%$.

Kurangnya pemahaman materi konsep mol juga disebabkan oleh motivasi dan minat siswa serta metode pembelajaran yang diberikan oleh guru dalam kegiatan pembelajaran konsep mol yang masih menggunakan pembelajaran konvensional. Dalam pembelajaran konvensional yang menggunakan metode ceramah pembelajaran masih berpusat pada guru sehingga siswa tidak berperan aktif dalam menganalisa dan memecahkan masalah. Kurangnya kemampuan menganalisa dan kemampuan matematik untuk perhitungan kimia juga menjadi faktor yang membuat konsep mol sulit dipahami, ini didukung oleh penelitian yang menyatakan bahwa kemampuan matematik berpengaruh terhadap prestasi belajar siswa dalam aspek pengetahuan pada pokok bahasan konsep mol [3].

Guru sebagai pendidik dapat melakukan inovasi dalam proses pembelajaran, menjadikan lingkungan belajar yang memadai dengan cara kreatif dan inovatif sehingga siswa dapat mempelajari materi dengan baik. Penting bagi siswa untuk berperan langsung dalam penemuan, penyelidikan dan penyelesaian masalah secara langsung dalam proses pembelajaran sehingga minat dan motivasi belajar siswa terhadap kimia dapat meningkat. Salah satu pembelajaran yang melibatkan siswa secara aktif adalah Process Oriented Guided Inquiry Learning (POGIL). POGIL adalah pendekatan instruksional yang memadukan inkuiri terbimbing dan pembelajaran kooperatif di mana siswa terlibat dalam proses pembelajaran kimia [4].

Tujuan dari penelitian ini adalah untuk mengetahui penerapan metode POGIL pada materi Konsep Mol di kelas X IPA SMA Negeri 2 Langowan.

\section{Metode}

Penelitian ini dilaksanakan di SMA Negeri 2 Langowan pada semester genap tahun ajaran $2018 / 2019$. Jenis penelitian yang digunakan dalam penelitian ini adalah penelitian eksperimen. Rancangan penelitian yang digunakan adalah Posttest Only Control Design. Seperti pada tabel 1 .

Tabel 1. Rancangan penelitian Posttest Only

\begin{tabular}{lll}
\multicolumn{3}{c}{ Control Design } \\
\hline Kelompok & Perlakuan & Posttest \\
\hline POGIL & $\mathrm{X}$ & $\mathrm{O}_{1}$ \\
\hline Ceramah & - & $\mathrm{O}_{2}$ \\
\hline
\end{tabular}

\section{Hasil dan Pembahasan}

Penelitian penerapan metode POGIL ini dilakukan di SMA Negeri 2 Langowan, dilakukan terhadap dua kelas yang dijadikan sampel penelitian. Kedua kelas tersebut adalah kelas X IPA 1 sebagai kelompok eksperimen yang diajarkan dengan menerapkan model pembelajaran POGIL dan kelas XI IPA 2 sebagai kelompok kontrol yang diajarkan dengan metode pembelajaran konvensional. Jumlah sampel penelitian yang digunakan sebanyak 46 siswa diantaranya 23 siswa di kelompok eksperimen dan 23 siswa di kelompok kontrol Setelah pelaksanaan pembelajaran di kelompok eksperimen dan kelompok kontrol, diperoleh data hasil belajar konsep mol yang didapat dari hasil tes akhir (post-test). Untuk itu bisa dilihat hasil posttest pada Tabel 2. 
Tabel 2. Data Post-test Kelas Problem Based Learning dan Kelas Ceramah

\begin{tabular}{cccc}
\hline No & $\begin{array}{c}\text { Jenis } \\
\text { Penilaian }\end{array}$ & $\begin{array}{c}\text { Kelas } \\
\text { Problem } \\
\text { Based } \\
\text { Learning }\end{array}$ & $\begin{array}{c}\text { Kelas } \\
\text { Ceramah }\end{array}$ \\
\hline 1. & $\begin{array}{c}\text { Skor } \\
\text { Minimum }\end{array}$ & 75 & 58 \\
\hline 2. & $\begin{array}{c}\text { Skor } \\
\text { Maksimum }\end{array}$ & 91 & 83 \\
\hline 3. & Mean & 83,47 & 74,04 \\
\hline
\end{tabular}

Pengujian Instrumen Peneliian

Uji Validitas

Uji validitas soal pada penelitian ini diuji cobakan kepada 20 orang siswa kelas XI IPA 1 di SMA Negeri 2 Langowan, dengan jumlah 20 bobot soal pilihan ganda, kriteria dinyatakan valid jika rhitung $>$ rtabel.

\section{Uji Reliabilitas}

Untuk uji reliabilitas, data yang didapat yaitu $\mathrm{r}_{11}=0,870>$ rtabel $=0,443$ sehingga reliabel atau akurat data yang diukur. Maka dari itu berarti instrumen tes yang di ukur reliabel

\section{Uji Normalitas}

Uji normalitas pada data yang telah di dapat, untuk kelas POGIL dan Konvensional dianalisis menggunakan Uji Liliefors. Dengan data yang telah diuji diperoleh pada perlakuan menggunakan metode POGIL kelas POGIL Lhitung $=0,078$ dan nilai Ltabel $=0,173$ pada taraf $\alpha$ $=0,05$ dengan $n=25$. Kesimpulannya data kelas POGIL berdistribusi normal. Pada kelas Ceramah Lhitung $=0,072$ dan nilai Ltabel $=0,173$ pada taraf nyata $\alpha=0,05$ dengan $\mathrm{n}=23$. Dengan demikian Lhitung < Ltabel maka kesimpulannya data kelas Konvensional berdistribusi normal.

\section{Uji Homogenitas}

Pada uji homegenitas mempunyai kriteria pengujian: Tolak $\mathrm{H}_{0}$ Jika Fhitung $<\mathrm{F}_{\text {tabel }}$ pada taraf nyaata $\alpha=0,05$, dengan hasil pengujian Fhitung = $1,17<\mathrm{F}_{\text {tabel }} 2,07$. Maka dapat disimpulkan bahwa kedua kelas adalah homogen.

\section{Uji Hipotesis}

Tabel 3. Ringkasan Uji Hipotesis

\begin{tabular}{lcc}
\hline \multicolumn{1}{c}{ Statistik } & $\begin{array}{l}\text { Kelas } \\
\text { POGIL }\end{array}$ & Kelas Ceramah \\
\hline $\begin{array}{l}\text { Jumlah } \\
\text { responden }\end{array}$ & 23 & 23 \\
\hline $\begin{array}{l}\text { Rata-rata } \\
\text { selisih }\end{array}$ & 83,47 & 74,04 \\
\hline $\begin{array}{l}\text { Simpangan } \\
\text { baku }\end{array}$ & 7,02 & 7,58 \\
\hline Varians & 49,33 & 57,50 \\
\hline t tabel & 1,68 & 1,68 \\
\hline
\end{tabular}

Dari hasil pengujian hipotesis diperoleh nilai thitung $=4,31$ pada taraf signifikan $\alpha=0,05$ dengan derajat kebebasan $(\mathrm{dk})=44$ diperoleh $t_{\text {tabel }}=1,68$. Karena nilai thitung $>$ tabel, maka $\mathrm{H}_{1}$ diterima dan $\mathrm{H}_{\mathrm{o}}$ ditolak.

Penelitian yang dilakukan di SMA Negeri 2 Langowan menunjukan bahwa hasil belajar materi konsep mol pada kelas eksperimen (X IPA 2) yang diajarkan dengan metode POGIL lebih besar dari hasil belajar siswa kelas kontrol (X IPA 1) yang diajarkan dengan metode konvensional. Hal ini dibuktikan dengan nilai rata-rata hasil belajar kelompok eksperimen lebih tinggi daripada nilai rata-rata hasil belajar kelompok kontrol. Nilai rata-rata hasil belajar ini diambil berdasarkan tes akhir (posttest) dengan menggunakan instrumen tes yang telah valid dan reliabel karena telah diuji validitas dan reliabilitasnya terlebih dahulu.

Perbedaan hasil belajar kelompok eksperimen yang diajarkan menggunakan metode pembelajaran POGIL dengan kelompok kontrol yang diajarkan menggunakan pembelajaran konvensional disebabkan karena dengan metode POGIL siswa dapat lebih mudah memahami atau memaknai materi konsep mol yang diajarkan. Berbeda pada kelompok kontrol, hanya menggunakan pembelajaran konvensional.

Pada kelas kontrol siswa diajarkan dengan menggunakan pembelajaran konvensional. Peneliti menjelaskan materi konsep mol dengan metode ceramah. Peneliti memberikan motivasi kepada siswa dalam kegiatan pembelajaran yaitu dengan memberitahukan bahwa guru memberikan skor bagi setiap siswa yang bertanya ataupun yang menjawab pertanyaan, 
dan yang mendapat skor tertinggi akan diberikan hadiah, pada awal kegiatan berlangsung siswa terlihat aktif untuk mengajukan pertanyaan kepada peneliti, ketika guru bertanya siswa memberikan respon yang baik, namun setelah peneliti mulai menjelaskan pada inti materi konsep mol, siswa mulai bosan dalam kegiatan pembelajaran, sebagian siswa kurang serius dalam proses pembelajaran, tidak bertanya dan masih banyak siswa yang tidak memperhatikan penjelasan dan arahan dari peneliti.

Pada kelas Eksperimen diajarkan dengan menggunakan metode POGIL dilaksanakan berdasarkan pada 7 tahapan yang memberikan kesempatan pada siswa untuk aktif selama proses pembelajaran. Pertama (engage) merupakan tahapan awal pembelajaran, peneliti mengawali kegiatan pembelajaran dengan memberikan gambaran tentang perhitungan dalam kehidupan sehari-hari, selanjutnya memberikan pertanyaan untuk menghubungkan (elicit) dengan materi konsep mol.

Pada tahapan explore peneliti membentuk kelompok-kelompok dan memberikan penjelasan mengenai materi kosep mol, selanjutnya siswa diberikan LKS dan dilibatkan dalam kegiatan eksplorasi yaitu demonstrasi video dan praktikum. Setelah itu peneliti mengarahkan siswa untuk berdiskusi dan bekerja sama dalam kelompok, melalui proses ini siswa terlihat semangat dalam berdiskusi dengan teman kelompoknya. Pada tahapan explain peneliti menginstruksikan tiap kelompok mengutus satu orang untuk menjelaskan hasil diskusi kelompok.

Pada tahap Elaborate peneliti memberikan kesempatan kepada siswa untuk menerapkan pengetahuan yaitu masing-masing kelompok membuat soal dan jawabannya, pada tahapan ini siswa terlihat aktif bekerja sama untuk membuat soal. Peneliti mengamati siswa dan mengarahkan siswa ketika mengalami kesulitan dalam kegiatan pembelajaran. Selanjutnya tahap Elaborate and Extend, peneliti memberikan soal untuk memeriksa pengetahuan siswa, soal tidak lagi dikerjakan secara kelompok tapi dikerjakan secara individu. Pada tahap akhir yaitu Evaluation/evaluate peneliti memeriksa jawaban berdasarkan soal yang sudah diberikan, selanjutnya peneliti memberikan penjelasan mengenai penyelesaian untuk soal yang belum dipahami siswa.

Langkah-langkah pembelajaran POGIL ini membuat siswa dapat berperan aktif dalam pembelajaran, menemukan pengetahuan sendiri namun tidak lepas dari bimbingan dan bekerja sama dalam kelompok. Siswa tertarik dan berperan aktif dalam pembelajaran sehingga hasil belajar yang diperoleh siswa yang diajarkan dengan metode POGIL lebih besar dari hasil belajar siswa yang diajarkan dengan metode konvensional.

Hasil yang didapatkan dalam penelitian ini relevan dengan penelitian penerapan pembelajaran POGIL dilengkapi LKS dapat meningkatkan prestasi belajar siswa [5]. Hal ini juga sejalan dengan penelitian pengaruh penggunaan model Modified Free Inquiry dan POGIL pada materi elektrolisis yang menyatakan bahwa melalui POGIL siswa lebih terarah dalam menentukan pemecahan masalah sehingga tidak mengalami kesulitan dalam penyelesaian masalah [6].

\section{Kesimpulan}

Berdasarkan hasil penelitian yang telah peneliti lakukan, maka dapat disimpulkan bahwa hasil belajar siswa dengan penerapan metode POGIL lebih besar dari hasil belajar siswa yang diajarkan dengan metode konvensional pada materi konsep mol di kelas $X$ IPA SMA Negeri 2 Langowan. Hal ini ditunjukkan oleh hasil uji-t diperoleh thitung $>t_{\text {tabel }}$ yaitu $4,31>1,68$.

\section{Daftar Pustaka}

1. Setiowati, H; Nugroho, A; Agustina, W. Penerapan Model Pembelajaran Inkuiri Terbimbing (Guided Inquiry) Dilengkapi Lks Untuk Meningkatkan Aktivitas Dan Prestasi Belajar Siswa Pada Materi Pokok Kelarutan Dan Hasil Kali Kelarutan Kelas Xi Mia Sma Negeri 1 Banyudono Tahun Pelajaran 2014/2015. JPK. 2015. Vol. 4. Hal. 54

2. Saragih, S; Sari, M; Edyanto; Silaban, R. Pengaruh Strategi Pembelajaran POGIL Dengan Animasi Komputer Terhadap Motivasi Dan Hasil Belajar Siswa SMA 
Pada Materi Pokok Stoikiometri. Talenta Converence Science. 2019. Vol. 2.Hal. 226. DOI 10.32734

3. Nurrochma, A; Saputro, S; Mulyani, S. Studi Komparasi Model Pembelajaran Team Asisted Individualization (TAI) dan Group Investigation (GI) Dengan Memperhatikan Kemampuan Matematik Terhadap Prestasi Belajar Siswa Pada Materi Stoikiometri Pokok Bahasan Konsep Mol Kelas X SMA Negeri 1 Boyolali Tahun Pelajaran 2015/ 2016. JPK. 2017. Vol. 2. Hal. 100.

4. Sen, S; Yilmaz, A; Gebar, O; The Effect Of Process Oriented Guided Inquiry Learning Environment on students self-regulated learning skills. Problems of Education In The 21st Century. 2015. Vol. 66. Hal 54.

5. Sari, W; Nugroho, A; Masykuri, M. Penerapan Pembelajaran Process Oriented Guided Inquiry Learning (POGIL) Dilengkapi LKS Meningkatkan Kemandirian dan Prestasi Belajar Siswa. Jurnal Profesi Pendidik. 2016. Vol. 3. Hal. 125.

6. Widyaningsih, S; Haryono; Saputro, S; Model MFI dan POGIL Ditinjau Dari Aktivitas Belajar Dan Kreatifitas Siswa Terhadap Prestasi Belajar. Jurnal Inkuiri. 2012. Vol. 1. Hal. 270 